SPECIAL VOLUME

\title{
Geochemistry and tectonic setting of the supracrustal rocks from the central part of the Bundelkhand Craton, India
}

\author{
M.M. Singh ${ }^{1}$, Vinod K. Singh ${ }^{1}$ * \\ ${ }^{1}$ Department of Geology, Bundelkhand University, Jhansi, UP, India-284128
}

\begin{abstract}
* Corresponding author : vinodksingh@bujhansi.ac.in
Tel.: +91-9415258237; fax: +91-5102321667

Received: Sept 25, 2018; Accepted: Feb 22, 2019.

DOI: 10.25299/jgeet.2019.4.2-2.2175
\end{abstract}

\begin{abstract}
Supracrustal rocks (mafics and ultramafics) occurs along with banded iron formation, and felsic volcanics around Babina, Dhaura, and Mauranipur linear east-west trends in central part of the Bundelkhand Craton represent Archean crust. The mafic and ultramafic rocks geochemically classified into Komatiite and Basaltic Komatiite and have high-Fe Tholeiitic in composition which may relate with the primitive mantle. The major and trace element geochemistry of mafic and ultramafic rocks correspond to hydrated mantle with wedge tectonic sources and ocean ridge geological characteristics.
\end{abstract}

Keywords: Bundelkhand Craton, Komatiite, island arc, Archean crust, subduction tectonic setting.

\section{Introduction}

Archean cratons of the world have become the nerve centers for study to decode the earlier crustal history of earth. The formation of supracrustal rocks or first landmass is in fact an irreversible process in the geological history of earth, which led the processes of initiation of stabilization, continental growth, micro-continent, and supracontinental growth (Pearce and Peate, 1995; Fitton et al., 2003; Naqvi, 2005; Condie, 2014, 2015). The Archean-Proterozoic boundary is an important turnover in the Earth's evolution as marking a cardinal change from the island arc and collisional settings of the Archean to the lithospheric extension and global continental rifting in the early Paleoproterozoic (Bogina et al., 2015). The Indian shield comprises two major Northern (Bundelkhand, Aravalli carton) and Southern (Dharwar, Bastar, Singhbhum Craton) Indian crustal blocks separated along the E-W trending Son-Narmada lineament known as Central Indian Tectonic Zone (Naqvi, 2005; Ramakrishnan and Vaidyanadhan, 2010; Slabunov and Singh, 2018). Mostly the central part of each craton consisting of TTG-gneisses and granitoids, commonly associated with sequences of meta-sedimentaries, metavolcanics and unstratified ultramafic and mafic volcanic rocks (Naqvi, 2005; Mohan et al., 2013; Jayananda et al., 2015).

The Bundelkhand Craton begin with the ca. $3.55 \mathrm{Ga}$ crustal component growth signatures around the Babina and Mauranipur areas, as preserve in the form of TTG-gneissic rocks (Sarkar et al., 1996; Mondal et al., 2002; Kaur et al., 2014; Singh, 2015; Saha et al., 2016; Singh et al., 2019a). The ca. 3.4 Ga ancient basaltic rocks are mostly exposed contemporaneous with TTG in central part of the craton (Singh et al., 2018, 2019b). The mafics and ultramafic rocks are widely exposed around Baragaon, Dhaura, Babina villages. Singh and Slabunov (2015a) suggest two distinct greenstone complex occur in the craton i.e. (i) Central Bundelkhand (Babina; Mauranipur belts) greenstone and (ii) Southern Bundelkhand (Girar) schist belts. Singh $(2005,2015)$ has carried out detailed study on geology and structure of Babina-Mauranipur areas and in present paper authors using petrological and geochemical data to determine tectonic settings of these Archean basaltic rocks of the central Bundelkhand Craton.

\section{Geological setting of Bundelkhand Craton}

The Bundelkhand Craton covers $29,000 \mathrm{~km} 2$, lying between $24^{\circ} 11^{\prime}$ to $26^{\circ} 27^{\prime} \mathrm{N}$ and $78^{\circ} 10^{\prime}$ to $81^{\circ} 24^{\prime} \mathrm{E}$, represents a semicircular outcrop, which is overlain by low grade metamorphic rocks of the Bijawar Group (Paleoproterozoic) to the south, southeast, and Vindhyan Supergroup (Mesoproterozoic to Neoproterozoic) to the southeast, south, southwest, and west (Basu, 1986; Sarkar et al., 1996; Singh et al., 2007; Ramakrishnan and Vaidyanadhan, 2010; Fig. 1). The major part of the craton comprises the different phases of Archean magmatism, low-grade metamorphism, Paleoproterozoic mafic dykes and quartz veins. Singh $(2005,2015)$ mapped the older crustal components from the central part of the Bundelkhand Craton which are scattered in the E-W shear zones 
of 3-5 km width (Fig. 2). Metabasics, banded iron formation (BIF) and felsic volcanic rocks exposed from $3 \mathrm{~km}$ south of the Babina town to Mauranipur in the east consider as a part of the Central Bundelkhand greenstone complex (Singh and Slabunov, 2015a, 2015b; Slabunov and Singh, 2018; Fig. 1). The doleritic dykes are usually dark greyish green in colour and have NNW-SSE to NW-SE trend (Basu, 1986; Sharma and Rahman, 2000; Pradhan et al., 2012). These mafic dykes are subalkaline to tholeiitic in composition and display continental affinity (Pati et al., 2008). A general characteristic of highly jointed quartz veins occur mostly about NE - SW to NNE-SSW trend.

The supracrustal rock comprises mafic-ultramafic rocks, banded iron formations, felsic volcanics occur along E-W linear trends, generally dipping towards north. Fragments of low-grade metamorphosed mafic-ultramafic rocks are occur nearby boundary between banded iron formation and TTG-gneisses, at the south of Babina area (near Pura village), Mauranipur and Dhaura villages (Figs. 1 and 2). These rocks are intruded by K-rich granitoids $(\sim 2500 \mathrm{Ma})$ at Babina, Dhaura and Rash Pahari near Mauranipur villages. The pegmatite veins are also observed at many places.

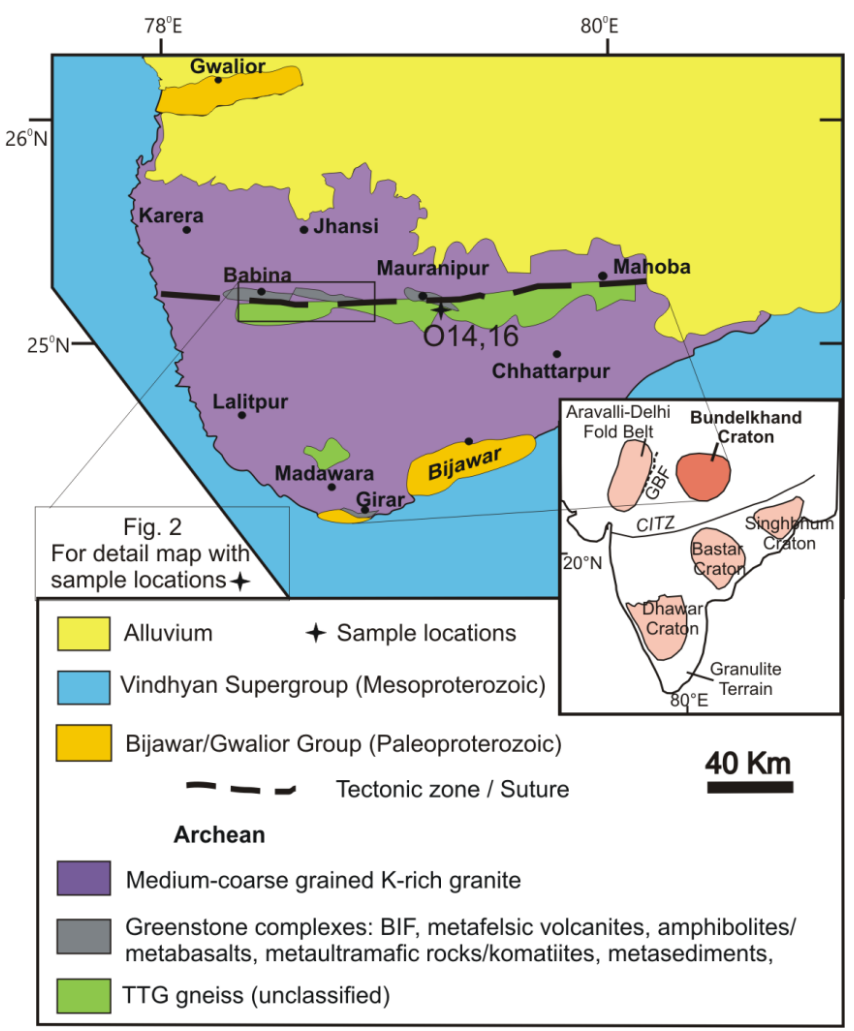

Fig. 1. Geological map of the Bundelkhand Craton (after Ramakrishnan and Vaidyanadhan, 2010 and Slabunov and Singh, 2018), inset map shows the different cratons of Indian shield.

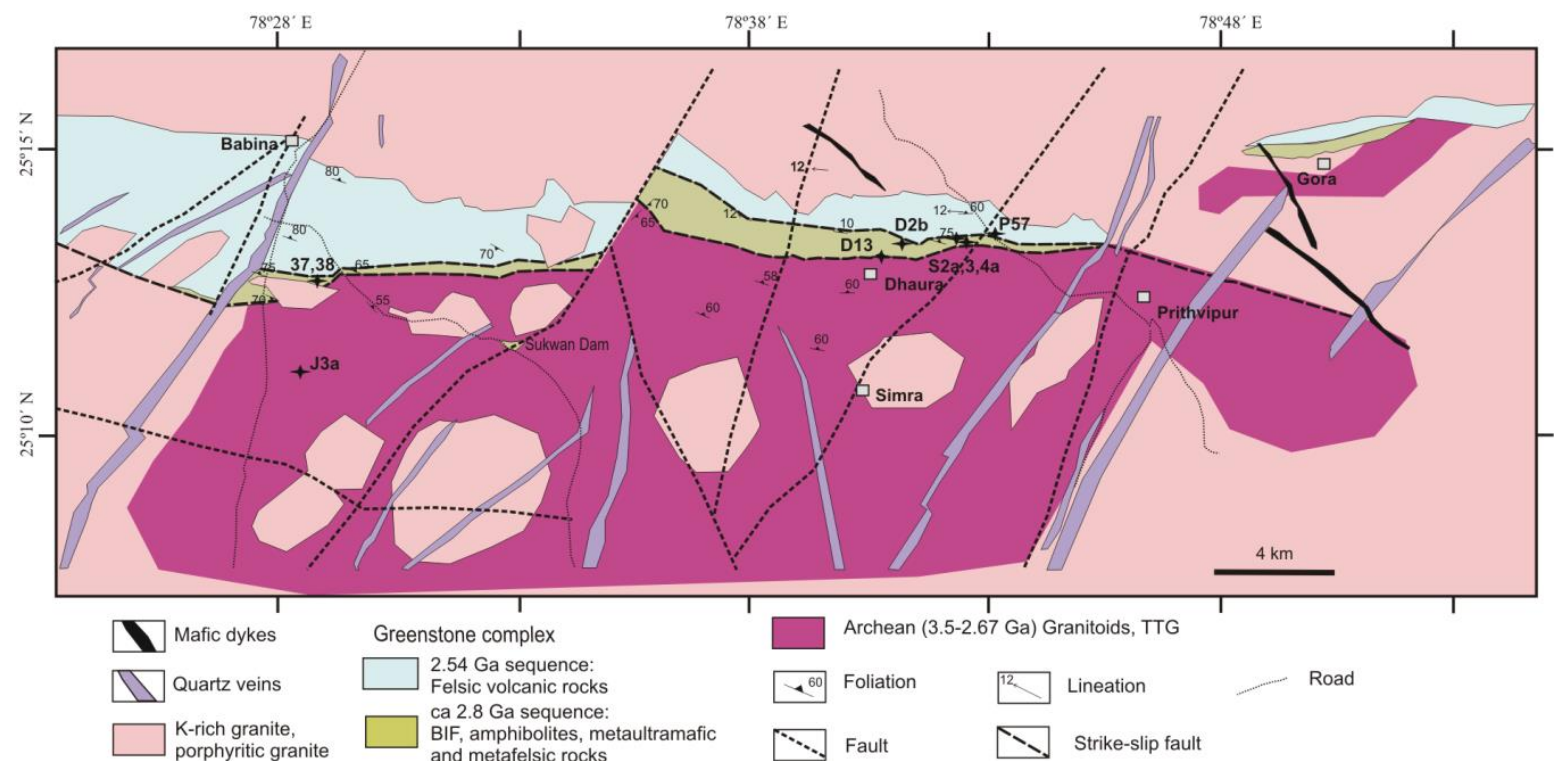

Fig. 2. Geological map of the Babina - Gora traverse, Central Bundelkhand greenstone complex (after Singh and Slabunov, 2015a). 
The small body of mafic and ultramafic rocks, exposed along with BIF near village Kuraicha in Mauranipur greenstone belt (Fig. 3a). Basic-ultrabasic rocks also exist in Babina greenstone belt (Fig. 3b) which is resembled with Mauranipur greenstone belt. Exposures of felsic volcanics are observed at north of Babina (Fig. 3c), Paponi, and Dhaura areas. Intrusions of granite are noticed in the felsic volcanics which indicate their younger age. TTGgneisses are exposed at Babina, Dhaura, Gora and Mauranipur areas. Field relation between basaltic, banded iron formation and TTG-gneisses rocks shows its tectonic colleagues (Fig. 3b; Singh and Slabunov, 2015a). The voluminous pink granites are mostly inhabit of the craton during Neoarchean period in multiple phases (Mondal et al., 2002; Verma et al., 2016; Kaur et al., 2016; Joshi et al., 2017; Mishra et al., 2018; Singh et al., 2019c). Slabunov and Singh (2018) noted that Meso-Neoarchean felsic rocks formed in a subduction geodynamic setting from the central Bundelkhand greenstone complex.

\section{Geochemistry and Tectonic setting}

Fresh samples of ultramafics and mafics from central Bundelkhand region have been collected and pulverized in agate ball mill for geochemistry. The samples have analysed at the geochemical lab of NGRI, Hyderabad for major, trace and REE using Inductively coupled Plazma Mass Spectrometry (ICP-MS) while XRF method was used at Wadia Institute of Himalayan Geology, Dehradun. The whole rock major and trace element compositions of the analysed samples are given in Table 1 . The different variation diagrams and discrimination diagrams have been obtained using the free access GCDkit 3.00 computer program.

The ultramafic and mafic rocks are classified as subalkaline/tholeiitic picritic, basalt to basaltic andesite with 36.56-55.15 $\mathrm{SiO}_{2}$ wt. \%(Fig. 4a). The rocks display a tholeiitic trend on the AFM diagram (Irvine and Baragar, 1971) (Fig. 4b). In the Jensen (1976) diagram, most rock points are into komatiite, komatiitic basalt, and high-Fe tholeiite fields (Fig. 4c). These rocks vary considerably in MgO (5.66-28.24 wt. \%), TiO2 (0.19-2.52 wt. \%), Ni (31$975 \mathrm{ppm}$ ) and $\mathrm{Cr}$ (67-3121 ppm) concentrations (Table 1). $\mathrm{Al}_{2} \mathrm{O}_{3}$ concentrations range from 6.58 to $14.25 \mathrm{Wt}$ \% The $\mathrm{Fe}_{2} \mathrm{O}_{3}$ in these rocks ranges from 11.89 to $24.3 \mathrm{wt}$. \%which is to some extent high value for tholeiitic magma. Geochemical compositions are plotted on several variation and tectonic diagrams against MgO vs oxides (wt. \% $\mathrm{TiO}_{2}$ and $\mathrm{P}_{2} \mathrm{O}_{5}$ ) and trace elements (ppm; $\mathrm{Rb}, \mathrm{Sr}, \mathrm{Y}$, and $\mathrm{Zr}$ ) to examine crystallization behavior, which show decreasing trend with increasing $\mathrm{MgO}$ contents (Fig. 5), suggesting that these were more or less incompatible with any fractionating phases.
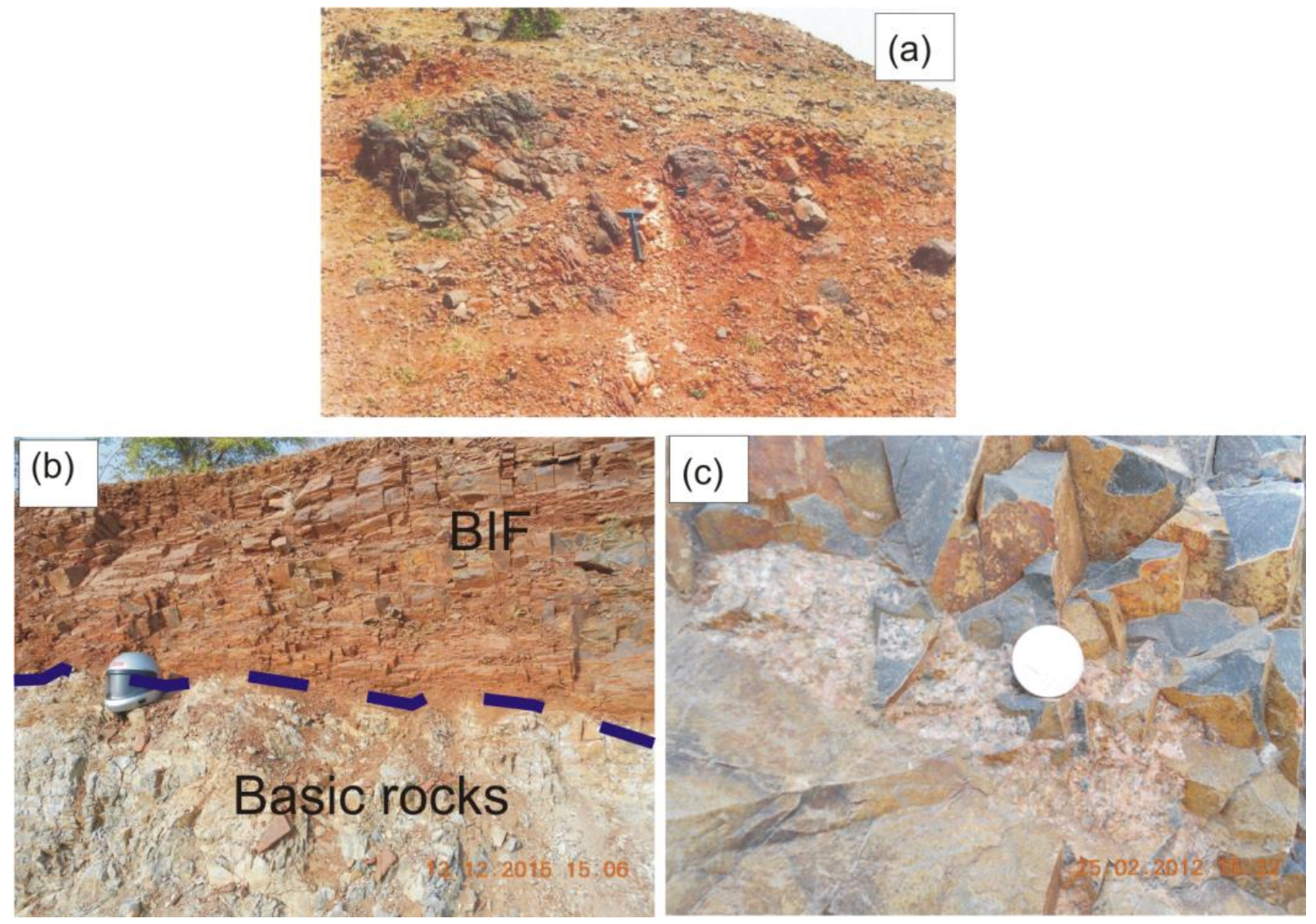

Fig.3. (a) The mafic and ultramafic rocks exposed at the base of BIF near village Kuraicha, Kamla Sagar dam in Mauranipur greenstone belt (size of hammer 15 inch); (b) the underlain basic rocks show tectonic contact with BIF exposed in Babina greenstone belt; (c) Felsic volacnics exposed at $3 \mathrm{~km}$ north of Babina with granite intrusion (size of coin $2.5 \mathrm{~cm}$ diameter). 

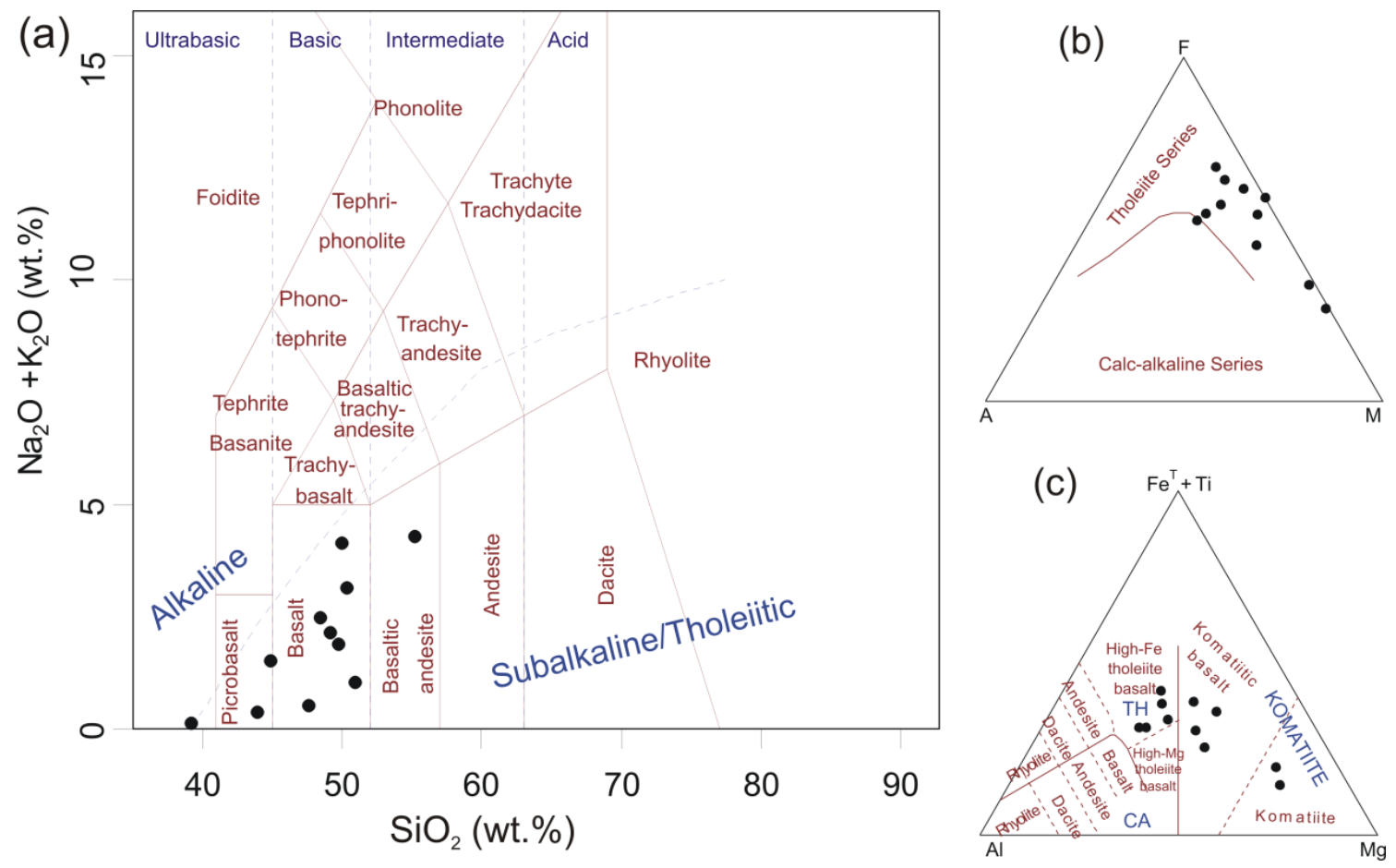

Fig. 4. Classification diagrams of mafic-ultramafic rocks (a) $\mathrm{SiO}_{2} \cdot \mathrm{Na}_{2} \mathrm{O}+\mathrm{K}_{2} \mathrm{O}$ (Le Bas et al. 1986), (b) AFM (Irvine and Baragar, 1971), (c) cation diagram $\mathrm{FeO}^{*}+\mathrm{TiO}_{2} \cdot \mathrm{Al} 2 \mathrm{O} 3 \cdot \mathrm{MgO}$ (Jensen, 1976).

Table 1. Major (wt. \% a and trace (ppm) element analytical data of Mafic and Ultramafic rocks from the central Bundelkhand greenstone complex.

\begin{tabular}{|c|c|c|c|c|c|c|c|c|c|c|c|}
\hline Sample & 014 & 016 & P57 & S2a & S3 & S4a & D2b & D13 & 37 & 38 & J3a \\
\hline Locality & Kuraicha & Kuraicha & Dhaura & Dhaura & Dhaura & Dhaura & Dhaura & Dhaura & Babina & Babina & Babina \\
\hline $\mathrm{SiO}_{2}$ & 44.23 & 36.56 & 42.4 & 48.06 & 49.58 & 55.15 & 51.31 & 50.92 & 49.72 & 49.18 & 47.81 \\
\hline $\mathrm{TiO}_{2}$ & 0.19 & 1.56 & 2.52 & 0.51 & 2.01 & 2.22 & 0.79 & 1.53 & 1.03 & 1.36 & 0.61 \\
\hline $\mathrm{Al}_{2} \mathrm{O}_{3}$ & 9.15 & 10.37 & 11.56 & 6.58 & 11.53 & 13.07 & 9.61 & 14.25 & 11.72 & 10.87 & 10.86 \\
\hline $\mathrm{Fe}_{2} \mathrm{O}_{3}$ & 11.89 & 24.3 & 23.5 & 12.51 & 17.76 & 12.28 & 14.22 & 14.98 & 16.11 & 19.98 & 13.63 \\
\hline $\mathrm{MnO}$ & 0.22 & 0.35 & 0.19 & 0.27 & 0.23 & 0.18 & 0.17 & 0.23 & 0.24 & 0.28 & 0.24 \\
\hline $\mathrm{MgO}$ & 28.24 & 14.99 & 11.55 & 21.29 & 6.91 & 5.66 & 9.62 & 6.9 & 7.74 & 6.26 & 12.21 \\
\hline $\mathrm{CaO}$ & 6.35 & 4.7 & 1.22 & 11.11 & 9.55 & 6.75 & 13.95 & 8.77 & 9.04 & 9.85 & 10.94 \\
\hline $\mathrm{Na}_{2} \mathrm{O}$ & 0.33 & 0.02 & 0.95 & 0.42 & 1.6 & 2.82 & 0.06 & 2.6 & 2.48 & 1.72 & 1.44 \\
\hline $\mathrm{K}_{2} \mathrm{O}$ & 0.06 & 0.03 & 0.47 & 0.1 & 0.27 & 1.48 & 1 & 1.61 & 0.62 & 0.44 & 1 \\
\hline $\mathrm{P}_{2} \mathrm{O}_{5}$ & 0.04 & 0.21 & 0.13 & 0.09 & 0.24 & 0.35 & 0.11 & 0.17 & 0.11 & 0.14 & 0.07 \\
\hline $\mathrm{Cu}$ & 85 & 31 & 47 & & 28 & 175 & 39 & 20 & & & 99 \\
\hline $\mathrm{Zn}$ & 120 & 131 & 101 & & 83 & 105 & 72 & 130 & & & 131 \\
\hline Co & 59 & 75 & 60 & & 51 & 59 & 73 & 80 & & & 78 \\
\hline $\mathrm{Ni}$ & 900 & 118 & 51 & 975 & 75 & 31 & 69 & 93 & 63 & 34 & 255 \\
\hline Ga & 15.9 & 16.7 & 12.1 & & 20.5 & 17.5 & 7.4 & 26.9 & & & 8.7 \\
\hline $\mathrm{Rb}$ & 2.7 & 3.5 & 13 & 5.8 & 18 & 81 & 34.9 & 48.2 & 42.5 & 8.1 & 61.3 \\
\hline $\mathrm{Ba}$ & 129 & 68 & 44 & & 492 & 135 & 45 & 102 & & & 114 \\
\hline Sr & 12 & 299 & 9 & 68 & 140 & 208 & 174 & 163 & 144 & 106 & 82 \\
\hline $\mathrm{Y}$ & 23.7 & 30.5 & 16.1 & & 21.7 & 25.4 & 9.7 & 34.6 & & & 14 \\
\hline $\mathrm{Zr}$ & 7 & 808 & 199 & 30 & 166 & 277 & 77 & 110 & 89 & 102 & 35 \\
\hline $\mathrm{Nb}$ & 1 & 67.3 & 7 & 2.7 & 11 & 18 & 4.1 & 7 & 4.7 & 5 & 2.8 \\
\hline Th & 1.9 & 5.8 & 2.5 & & 2 & 0.5 & 1.6 & 49.2 & & & 3.3 \\
\hline $\mathrm{Sc}$ & 51 & 60 & 45 & & 58 & 43 & 40 & 36 & & & 24 \\
\hline $\mathrm{Pb}$ & 11.7 & 10 & 8 & & 9.8 & 2.8 & 14.6 & 27.5 & & & 19.1 \\
\hline$U$ & 1.4 & 0.3 & 1.8 & & 1.1 & 1.4 & 0.3 & 1.9 & & & 0.5 \\
\hline $\mathrm{Cr}$ & 67 & 105 & 908 & & 370 & 170 & 3121 & 743 & & & 2441 \\
\hline $\mathrm{Nb} / \mathrm{Th}$ & 0.53 & 11.60 & 2.8 & & 5.5 & 36 & 2.56 & 0.14 & & & 0.85 \\
\hline $\mathrm{Zr} / \mathrm{Nb}$ & 7 & 12.01 & 28.43 & 11.11 & 15.09 & 15.39 & 18.78 & 15.72 & 18.94 & 20.4 & 12.5 \\
\hline $\mathrm{Nb} / \mathrm{Y}$ & 0.04 & 2.21 & 0.44 & & 0.51 & 0.71 & 0.42 & 0.20 & & & 0.2 \\
\hline $\mathrm{Zr} / \mathrm{Y}$ & 0.30 & 26.49 & 12.36 & & 7.65 & 10.91 & 7.94 & 3.18 & & & 2.5 \\
\hline
\end{tabular}

The three fields of mantle domains i.e. enriched mantle (EM), depleted mantle (DM), and hydrated mantle (HM) are define using Nb/Th and Zr/Nb ratio discrimination plot (Condie, 2003, 2005, 2015). The ratios of Nb/Th 
is less than 8 and with variable $\mathrm{Zr} / \mathrm{Nb}$ ratio, show the Archean basalts mostly falls under hydrated mantle domain (Condie, 2015). The $\mathrm{Zr} / \mathrm{Nb}$ ratio is greater than 10 and Nb/Th less than 10 indicate arc setting (Condie, 2015). The samples from the central Bundelkhand greenstone belt plotted on diagram which show mostly hydrated mantle field and under arc setting conditions (Fig. 6). The sample no 016 which have $11.6 \mathrm{Nb} / \mathrm{Th}$ value likely consider an enriched mantle source (Condie, 2015). The sample no S4a have very high $\mathrm{Nb}$ /Th value (36) due to less value of Th noticed in specimen may not provide convincing interpretation.

Fitton et al. (2003) describe the $\mathrm{Nb} / \mathrm{Y}$ versus $\mathrm{Zr} / \mathrm{Y}$ discrimination diagram which distinguish NMORB and Iceland basalts on $\mathrm{Nb}$ incompatible element. The lower limit of Iceland data array as reference line defined a parameter $(\triangle \mathrm{Nb})$ that expresses excess or deficiency in Nb such that Icelandic basalt has $\Delta \mathrm{Nb}>0$ and NMORB show deficiency in $\mathrm{Nb}(\Delta \mathrm{Nb}<0$; Fitton et al., 2003). The mafic and ultramafic rocks from the central Bundelkhand greenstone complex plotted on Fitton et al. (2003) discriminant diagram which falls mostly in the vicinity of $\mathrm{Nb} / \mathrm{Zr}=0.06$ line with OIB field and some samples falls in Iceland basaltic type (Fig. 7).

The compositions of mafics and ultramafics rocks are associated to arc type tectonic setting for the magmatism. Singh et al. (2019b) suggest that the mafic-ultramafic rocks from central Bundelkhand greenstone complex have been interpreted to be derived from oceanic crust in a subduction-related setting with depleted mantle composition. Similar rocks are also reported by Malviya et al. (2006) from Mauranipur area and stated that komatiite basalt is nearly constant along the olivine fractional crystallization trend but enriched LREE and LILE as modern boninite formed at a plate convergent margin.
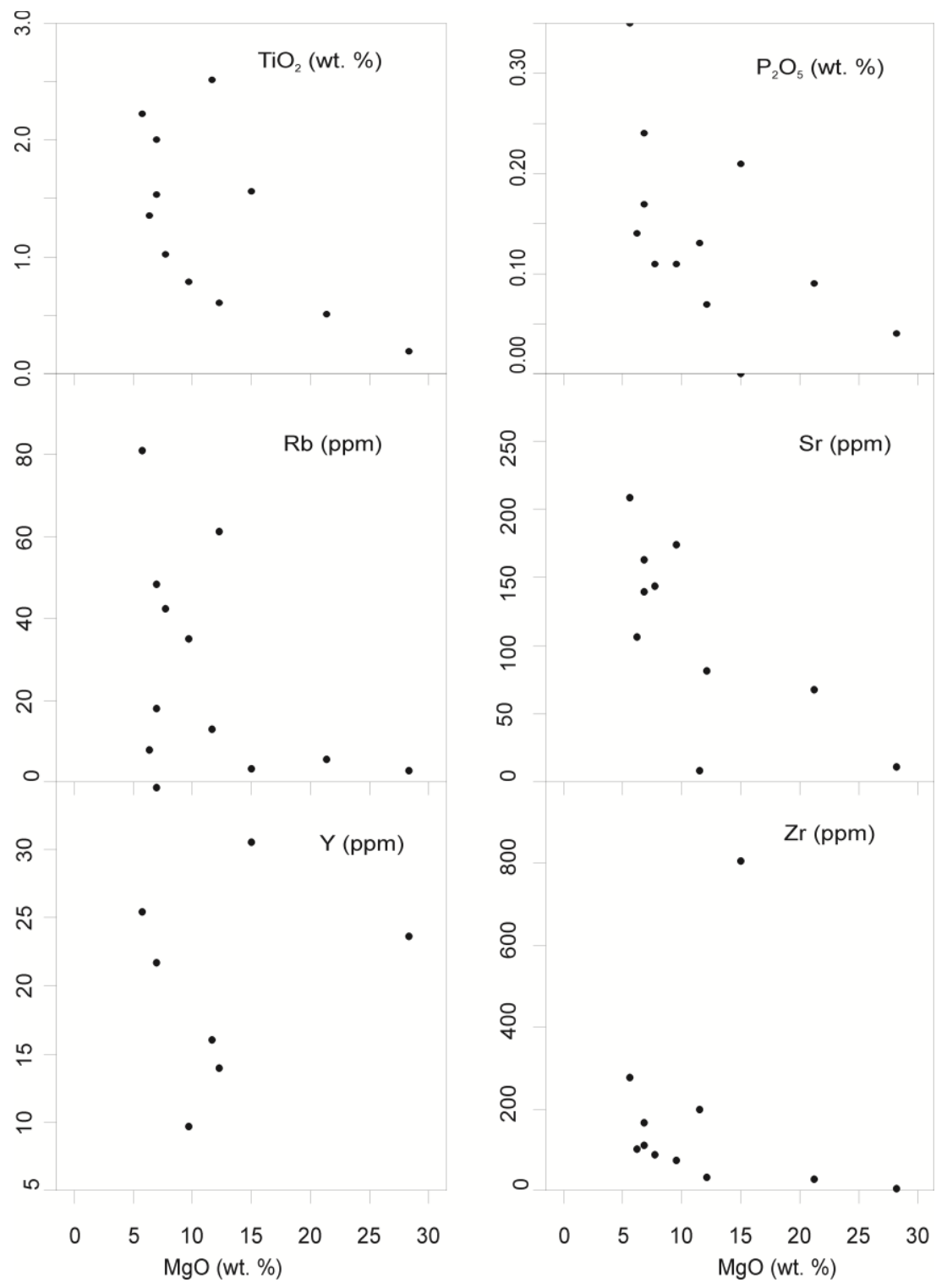

Fig. 5. Geochemical variation diagrams between $\mathrm{MgO}\left(\mathrm{wt} / \mathrm{g}\right.$ and minor oxides $\left(\mathrm{TiO}_{2}\right.$ and $\left.\mathrm{P}_{2} \mathrm{O}_{5} ; \mathrm{wt} / \mathrm{g}\right)$ and trace elements $(\mathrm{Rb}, \mathrm{Sr}$ $\mathrm{Y}$, and $\mathrm{Zr}$; in $\mathrm{ppm})$. 


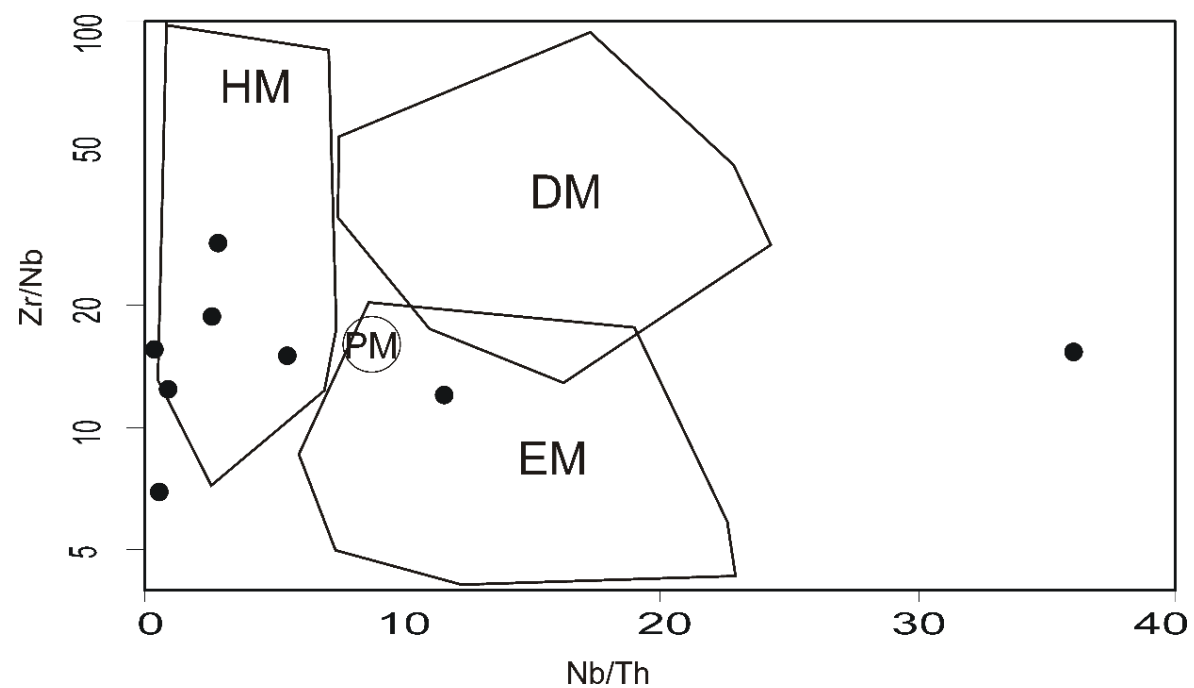

Fig. 6. Discrimination diagrams for distinguishing tectonic setting using Nb/Th and $\mathrm{Zr} / \mathrm{Nb}$ ratios (Condie, 2015).

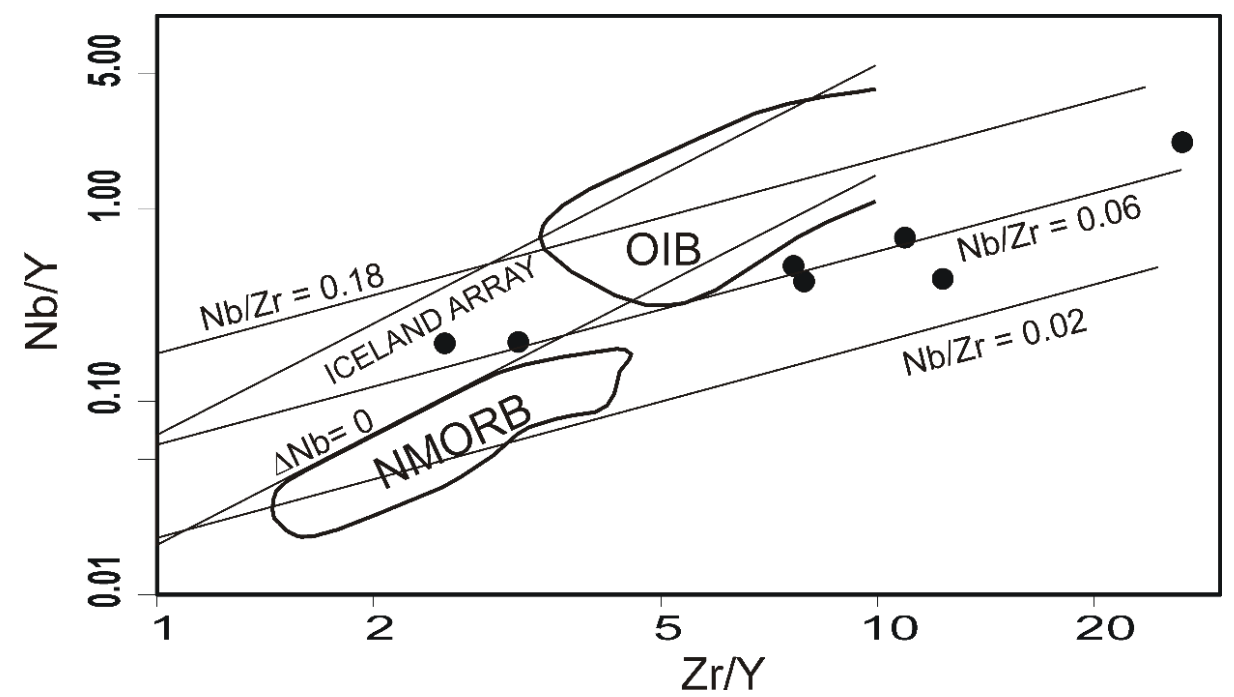

Fig. 7. Zr/Y versus Nb/Y discrimination diagram (after Fitton et al., 2003); NMORB: normal mid-ocean ridge basalt, OlB: oceanisland basalt.

\section{Discussion and Conclusions}

The supracrustal rocks of Babina and Mauranipur consist of low K-Tholeiitic basalt, basaltic Komatiite, volcanosediment and BIF followed by andesite to rhyodacite volcanics which are similar to those reported from various Archean greenstones (Paris, 1987; Kusky et al., 2001; Polat et al., 2003; Manikyamba et al., 2005). Condie (2015) discussed that $\mathrm{Nb} / \mathrm{Th}$ and $\mathrm{Zr} / \mathrm{Nb}$ incompatible element ratios are useful to illustrate their tectonic setting where the ratio of $\mathrm{Nb} / \mathrm{Th}$ is less than 8 and with variable $\mathrm{Zr} / \mathrm{Nb}$ ratio, falls under hydrated mantle domain mainly of Archean oceanic basalts. Several hypotheses have been discussed as accretions of oceanic terrain form by plume impact explain the unusual high MgO content of Komatiite (Hertzberg, 1995; Xie et al., 1995; Arndt et al., 1997) causes the large degree of melting and the pyrope-bearing peridotite source material is usually considered for the source of Komatiite magma. The accretion of oceanic volcanic arc may explain a geochemical similarity between Komatiite and modern arc related volcanic for supracrustal rocks of the central Bundelkhand region (Malviya et al. 2006).

The discussions of occurrences of metabasic and ultrabasic rocks and generation of various type of parent (Basaltic/Komatiitic) magma reveal related to different tectonic environment even in smaller tectonic provinces too (Bose, 1997; Barley et al., 2000; Massaki et al., 2001; Svetov et al., 2001; Shimizu et al., 2005; Verma et al., 2015). Fitton et al. (2003) provides a useful discriminant logarithmic plot of $\mathrm{Nb} / \mathrm{Y}$ versus $\mathrm{Zr} / \mathrm{Y}$ between Icelandic basalt and NMORB (i.e. plume and nonplume basalt). The $\mathrm{Nb} / \mathrm{Y}$ versus $\mathrm{Zr} / \mathrm{Y}$ plotted mafics and ultra-mafics rocks from central part of the Bundelkhand Craton show mostly OIB type plume basalt (Fig. 7). The initial Komatiite composition of magma altered to Komatiitic basalt and Tholeiitic compositions, either due to fractionation or 
contamination or metasomatic activities in the area. Geochemically the mafic and ultramafic rocks are very similar to the Komatiitic and Komatiite basalts of greenstone belts.

Singh and Slabunov (2015a) estimated as Paleo-Neoarchean time for the formation of supracrustal metabasic rocks from central Bundelkhand greenstone complex. The ultramafic and mafic sequences in Babina and Mauranipur greenstone belt are related to arc type subduction related magmatism (Malviya et al., 2006; Singh, 2015, Condie, 2015). Singh et al. $(2018,2019 b)$ stated that $\varepsilon N d t$ value of +2.0 to +5.6 for the basalts from Babina greenstone belt indicate depleted mantle source at ca.3.4 Ga.

Thus, the geochemical characteristics conclude that the protolith of supracrustal rocks of the central Bundelkhand greenstone complex be produced in hydrated mantle field with arc tectonic setting in Archean time. The Komatiitic-Tholeiitic association of greenstone formed in narrow belt along the Babina-Mauranipur greenstone belt.

\section{Acknowledgements}

MMS gratefully acknowledges financil support provided by Ministry of Mines, Government of India, New Delhi vide letter F. No.14/17/2002-Met.IV dated 27th February 2003 to Bundelkhand University Jhansi, UP. VKS is thankful to DST, Gov. of India, for providing the financial support as grants no. [INT/RUS/RFBR/P-279]. Prof. A.I. Slabunov (Petrozavodsk, Russia) and Neeraj Chaudhary thankfully acknowledged for discussions.

\section{References}

Arndt, N.T., Kerr. A.C., Tarney, J., 1997. Dynamic melting in plume heads: The formation of Gorgona komatiites and basalt. Earth and Planetary Science Letters 146, 289-301.

Barley, M.E., Kerrich, R., Reudavy, I., Xie, Q., 2000. Late Archean Ti-rich, Al-depleted komatiites and komatiitic volcaniclastic rocks from the Murchison Terrane in Western Australia. Australian Journal of Earth Sciences 47(5), 873-883.

Basu, A.K., 1986. Geology of parts of Bundelkhand granite massif, Central India. Record Geological Survey of India 117, $61-124$.

Bogina, M.M., Zlobin, V.L., Mints, M.V., 2015. Early Palaeoproterozoic volcanism of the Karelian Craton: age, sources, and geodynamic setting. International Geology Review 57 (11-12), 1433-1445.

Bose, M.K., 1997, Igneous Petrology. The World Press Private Limited, Calcutta.

Condie, K.C., 2003. Incompatible element ratios in oceanic basalts and komatiites: tracking deep mantle sources and continental growth rates with time. Geochem. Geophys. Geosyst. 4(1), http://dx.doi.org/10.1029/2002GC000333

Condie, K.C., 2005. High field strength element ratios in Archean basalts: a window to evolving sources of mantle plumes? Lithos 79, 491-504.

Condie, K.C., 2014. Growth of continental crust: a balance between preservation and recycling. Mineral. Mag. 78 (3), $623-637$.

Condie, K.C., 2015. Changing tectonic settings through time: Indiscriminate use of geochemical discriminant diagrams. Precambrian Research 266, 587-591.

Fitton, J.G., Saunders, A.D., Kempton, P.D., Hardarson, B.S., 2003. Does depleted mantle form an intrinsic part of the Iceland plume? Geochem. Geophys. Geosyst. 4(3), 1032, http://dx.doi.org/10.1029/2002GC000424

Hertzberg, C., 1995. Generation of plume magma through time an experimental perspective. Chemical Geology 126(1), 1-16.

Irvine, T.N., Barager, W.R.A., 1971. A guide to the chemical classification of the common volcanic rocks: Canadian Journal of Earth Sciences 8, 523-548.

Jayananda, M., Chardon, D., Peucat, J.-J., Tushipokla, Fanning, C.M., 2015. Paleo- to Mesoarchean TTG accretion and continental growth in the western Dharwar craton, Southern India: Constraints from SHRIMP U-Pb zircon geochronology, whole-rock geochemistry and Nd-Sr isotopes. Precambrian Research 268, 295-322.

Jensen, L.S., 1976. A New Cation Plot for Classifying Subalkalic Volcanic Rocks: Ontario Division of Mines, Miscellaneous Paper $66,22 \mathrm{p}$.

Joshi, K. B., Bhattacharjee, J., Rai, G., Halla, J., Ahmad, T., Kurhila, M., Heilimo, E., Choudhary, A. K., 2017. The diversi fication of granitoids and plate tectonic implications at the Archean-Proterozoic boundary in the Bundelkhand craton, Central India. In: Halla, J., Whitehouse, M.J., Ahmad, T., Bagai, Z. (eds.) Crust-Mantle Interactions and Granitoid Diversification: Insights from Archean Cratons. Geological Society London, Spec. Publ. 449, 123-157.

Kaur, P., Zeh, A., Chaudhri, N., 2014. Characterisation and U-Pb-Hf isotope record of the 3.55 Ga felsic crust from the Bundel khand craton, northern India. Precambrian Res. 255, 236-244.

Kaur, P., Zeh, A., Chaudhri, N., Eliyas, N., 2016. Unravelling the record of Archaean crustal evolution of the Bundelkhand Craton, northern India using $\mathrm{U}-\mathrm{Pb}$ zircon-monazite ages, $\mathrm{Lu}-\mathrm{Hf}$ isotope systematics, and whole-rock geochemistry of granitoids. Precambrian Research 281, 384-413.

Kusky, T.M. Jiang, H.L., Tucker, R.D., 2001. The Archean Dongwanzi ophiolite complex, North China craton: 2.505-billion year old oceanic crust and mantle. Science 292, 1142-1145.

Le Bas, T.M., Le Maitre, R.W., Streckeisen, A., Zanettin, B., 1986. A chamical classification of volcanic rocks on the total alkalisilica diagram: Journal of Petrology 27, 745-750.

Malviya, V.P., Arima, M., Pati, J.K., Kaneko, Y., 2006. Petrology and geochemistry of metamorphosed basaltic pillow lava and basaltic komatiite in the Mauranipur area: subduction related volcanism in the Archean Bundelkhand craton, Central India: Journal of Mineralogical and Petrological Sciences 101, 199-217.

Manikyamba, C., Naqvi, S.M., Subba Rao, D.V., Ram Mohan, M., Khanna, T.C., Rao, T. G., Reddy, G.L.N., 2005. Boninite from the Neoarchean Gadwal greenstone belt, eastern Dharwar craton, India: implication for Archean subduction processes. Earth and Planetary Science Letters 230, 65-83.

Massaki, O., Yasuhito, O., Tsuyoshi, T., Toshiaki, T., Tomokazu, H., Warwick, A.C., 2001. Petrography and geochemistry for mafic and ultramafic rocks from Tonagh Island in the Napier Comlex, East Antartica: A preliminary report. Journal of Polar Geoscience 12, 87-100.

Mishra, S., Singh, P.K., Singh, V.K., Slabunov, A.I., Nainwal, H.C., Chaudhary, N., 2018. Neoarchean Granitoids of Bundelkhand Craton, India: Geochemistry and Geodynamic Settings. Archaeology \& Anthropology: Open Access 3 (suppl-3), 114-123, https://doi.org/10.31031/AAOA.2018.03.000565 
Mohan, M.R., Piercey, S.J., Kamber, B.S. Sarma, D.S., 2013. Subduction related tectonic evolution of the Neoarchean eastern Dharwar Craton, southern India: New geochemical and isotopic constraints. Precambrian Research 227, 204-226.

Mondal, M.E.A., Goswami, J.N., Deomurari, M.P., Sharma, K.K., 2002. Ion microprobe 207Pb/206/Pb ages of zircon from the Bundelkhand massif, northern India: implication for crustal evolution of Bundelkhand - Aravalli protocontinent: Precambrian Research 117, 85-100.

Naqvi, S.M., 2005. Geology and Evolution of the Indian Plate (from Hadean to Holocene - 4Ga to 4Ka): Capital Publishing Company, New Delhi, 450.

Paris, L.A., 1987. The 3.5 Ga Barberton greenstone successions, South Africa: implication for modeling the evolution of Archaean crust. Journal of Geology, 5-24.

Pati, J.K., Raju, S., Malviya, V.P., Bhushan, R., Prakash, K., Patel, S.C., 2008, Mafic dykes of Bundelkhand craton, Central India: field, petrological and geochemical characteristics. In: Srivastava, R.K., Sivaji, Ch. and Chalapathi Rao, N.V. (Eds.), Indian Dykes: Geochemistry, Geophysics and Geochronology, Narosa Publishing House, New Delhi, 547-569.

Pearce, J.A., Peate, D.W., 1995. Tectonic implications of the composition of volcanic arc magmas. Annu. Rev. Earth Planet. Sci. $23,251-285$.

Polat, A., Hofmann, A.W., Munker, C., Regelous, M., Appel, P.W.U., 2003. Contrasting geochemical patterns in the 3.7-3.8 Ga pillow basalt cores and rims, Isua greenstone belt, South-west Greenland: implications for post magmatic alteration processes. Geochimica et Cosmochimica Acta 67, 441-457.

Pradhan, V.R., Meert, J.G., Pandit, M.K., Kamenov, G., Mondal, M.E.A., 2012. Paleomagnetic and geochronological studies of the mafic dyke swarms of Bundelkhand craton, central India: Implications for the tectonic evolution and paleogeographic reconstructions. Precambrian Research 198-199, 51-76.

Ramakrishnan, M., Vaidyanadhan, R., 2010. Geology of India, vol. 1: Geological Society of India, Bangalore, 556.

Saha, L., Frei, D., Gerdes, A., Pati, J.K., Sarkar, S., Patole, V., Bhandari, A., Nasipuri, P., 2016. Crustal geodynamics from the Archaean Bundelkhand Craton, India: constraints from zircon U-Pb-Hf isotope studies. Geological Magazine 153, 79-192.

Sarkar, A., Paul D.K., Potts, P.J., 1996. Geochronology and geochemistry of the Mid-Archean, Trondhjemitic gneisses from the Bundelkhand craton, Central India, in Saha, A.K., ed., Recent Researches in Geology 16, 76-92.

Sharma, K.K., Rahman, A., 2000. The Early Archean - Palaeoproterozoic crustal growth of the Bundelkhand Craton, Northern Indian Shield, in Dev, M., ed., Crustal Evolution and Metallogeny in the Northwestern Indian Shield, 51-72.

Shimizu, K., Nakamura, E., Maruyama, S., 2005. The Geochemistry of ultramafic to mafic volcanics from the Be-lingwe greenstone belt, Zimbabwe: Magmatism in an Arch-ean continental large igneous province. Journal of Petrology 46(11), 2367-2394.

Singh, M.M., 2005. Petrology of supracrustal rocks of Bundelkhand massif, Babina-Mauranipur transects, Uttar Pradesh. Unpublished Ph.D. thesis, Bundelkhand University, Jhansi.

Singh, M.M., 2015. Supracrustal rocks of Bundelkhand massif (granite, gneisses and volcano-metasedimentaries), LAP Lambart Academic publishing, Germany.

Singh, P.K., Verma, S.K., Moreno, J.A., Singh, V.K., Oliveira, E.P., 2018. Geochronology and Geochemistry of Basalts: Empirical evidences from the Babina and Mauranipur greenstone belts of the Bundelkhand craton, India. In: Goldschmidt Conference abstract, 2018.

Singh, P.K., Verma, S.K., Moreno, J.A., Singh, V.K., Malviya, P.K., Oliveira, E.P., Mishra, S., Arima, M., 2019b. Geochemistry and $\mathrm{Sm}-\mathrm{Nd}$ isotope systematics of metabasalts from the Babina and Mauranipur greenstone belts, Bundelkhand craton: Implications for tectonic setting and Paleoarchean mantle evolution. Lithos 330-331, 90-107.

Singh, P.K., Verma, S.K., Singh, V.K., Moreno, J.A., Oliveira, E.P., Mehta, P. 2019c. Geochemistry and petrogenesis of sanukitoids and high- $\mathrm{K}$ anatectic granites from the Bundelkhand craton: Implications for the late-Archean crustal evolution. J. of Asian Earth Sciences, 174C, 263-282, https://doi.org/10.1016/j.jseaes.2018.12.013

Singh, S.P., Singh, M.M., Srivastava, G.S., Basu, A.K., 2007. Crustal evolution in Bundelkhand area, Central India. Journal of Himalayan Geology 28(2), 79-101.

Singh, V.K., Slabunov, A., 2015a. The Central Bundelkhand Archaean greenstone complex, Bundelkhand craton, central India: Geology, composition, and geochronology of supracrustal rocks. Int. Geol. Rev. 57, 1349-1364.

Singh, V.K., Slabunov, A., 2015b. Geochemical characteristics of Banded Iron Formation and Metavolcanics of Babina greenstone belt of the Bundelkhand Craton, Central India. Journal of Economic Geology and Georesource Management 10, 63-74.

Singh, V.K., Nesterova, N., Slabunov, A., Singh, M.M., 2019a. Tectonic divisions of the Bundelkhand Craton Indian Shield: on the basis of geological, geophysical and Sm-Nd systematic of granitoids data. In Dwivedi, A.K., Purohit, R., (eds.), National Seminar on Geological Aspects of Northwest Indian Shield, on March 15-16, 2019 organised at Department of Geology, M.S. University, Udaipur, India, p. 32-33.

Slabunov, A.I., Singh, V.K., 2018. Meso-Neoarchaean crustal evolution of the Bundelkhand Craton, Indian Shield: new data from greenstone belts. International Geology Review, https://doi.org/10.1080/00206814.2018.1512906

Svetov, S.A., Svetova, A.I., Huhma, H. 2001. Geochemistry of the komatiite-tholeiite rock association in the Vedlozero-Segozero Archean greenstone belt, central Karelia. Journal of Geochemistry International 39 (Suppl. 1), S24-S38.

Verma, S.K., Oliveira, E.P., Verma, S.P., 2015. Plate tectonic settings for Precambrian basic rocks from Brazil by multidimensional tectonomagmatic discrimination diagrams and their limitations. Int. Geol. Rev. 57, 1566-1581.

Verma, S.K., Verma, S.P., Oliveira, E.P., Singh, V.K., and More, J.A., 2016. LA-SF-ICP-MS zircon U-Pb geochronology of granitic rocks from the central Bundelkhand greenstone complex, Bundelkhand craton, India. Journal of Asian Earth Sciences 118, $125-137$.

Xie, Q., Me Cuaig, T.C., Kerrich, R., 1995. Secular trends in the melting depth of mantle plumes: evidence from HFSE/ REE systematics of Archean high Mg lava and modern oce-anic basalt. Chemical Geology 126, 29-42. 